as to have any practical bearing on the behaviour of a secondary battery.

University College, Liverpool.

OLIVER J. LODGE

\section{On the Conservation of Solar Radiation}

I'r appears to me a difficulty arises with regard to Dr. Siemens' theory when we consider the original condition of the earth and of the other planets. What, in fact, has become of the great amount of energy which was present in the form of heat in those bodies?

Just as in the case of the sun, the rotation of the earth would produce a continuous cycle current, the decrease of rotatory energy being perhaps counterbalanced by shrinkage, the radiant heat wonld become transformed into the potential energy of dissociation, and this energy again would be given back to the earth in the form of heat in another part of the circuit where the elements recombine. Now it is quite impossible that the whole of the heat radiated should be used in this way, for after a lapse of years we should find a considerable diminution of potential, or (perhaps) rotatory erergy, and we therefore should be forced to the conclusion that the earth became continually hotter. Hence some of the radiant heat escaped must have escaped into space, never to return.

Is it then a feasible solution that more heat is radiating from the sun than is necessary for the dissociation of the elements? If so, then at least we should have a satisfactory explanation of its slowly-diminishing activity,

G. B. S.

THE writer of this letter is right in concluding that in accordance with my hypothesis the earth also must throw out a stream of matter equatorially into space; and if your correspondent will refer to my article in the Nineteenth Century of April last, he will find that at p. 522 I speak of such a terrestrial ontflow, with which I connect the phenomena of Aurora Borealis, If at any period of the world's history the rotatory velocity of the earth has been much greater than it is now, and its surfacetemperature sufficiently high to cause ignition of combustible gases, it may be reasonably supposed that it had the power of recuperating its heat of radiation. The amount of heat so recuperated would, under all circumstances, be less than that received back by combustion, and the result of gradnal diminution of temperature would be that on a certain day the temperature must have fallen below the point of ignition, from which day forward no further recuperation of heat could be expected. The process of cooling would then proceed at a very rapid ratio, until the surface-temperature had reached another point of comparative constancy, at which the radiation into space was balanced by the heat received by solar radiation, and which is our present condition.

I 2, Queen Anne's Gate, S.W., October 16

C. W. SiEMENS

\section{The Great Comet and Schmidt's Comet}

THERE can be no doubt of the elongation of the nucleus of the Great Comet in the direction of the axis of the tail, in which direction it is three times as long as in a direction at right angles thereto.

The place of the comet this morning, at $6 \mathrm{~h}$. om. G.M.T., was

$$
\text { R.A. }=\text { Ioh. } 18 \mathrm{~m}, 53 \pm 5 \mathrm{secs} \text {. }
$$$$
\text { P.D. }=103^{\circ} 3 \mathrm{I}^{\prime} 35^{\prime \prime} \pm 10^{\prime \prime} \text {. }
$$

A neighbouring object was carefully observed, through haze, as a star of reference; its place was

$$
\begin{aligned}
& \text { R.A }=10 h .18 \mathrm{~m} \cdot 53 \mathrm{~s} . \\
& \text { P.D. }=102^{\circ} 30^{\prime} \mathrm{O}^{\prime \prime}
\end{aligned}
$$

On consulting the Catalogne, it appears there is no star in this place. The object observed was probably Schmidt's Comet, discovered on the 8th of this month, but not since heard of here.

Unfortunately the above are absolute, not differential mea sures, but they have been corrected by measures of $\lambda$ Draconis, also observed as a star of reference; its place is

$$
\begin{aligned}
\text { R.A. } & =\text { Ioh. } 4 \mathrm{~m} .46 \mathrm{~s} . \\
\text { P.D. } & =101^{\circ} 46^{i} 27^{\prime \prime} .
\end{aligned}
$$

Sherrington House, Bray, October I 6

\section{WENTWORTH ERCK}

[The nearest bright star to Mr. Erck's place is L. 20158, 6.7 mag. in Gould ; R.A. for 1882 , Ioh. I 7m. 32s., N.P.D. IO2 $2^{\circ} 47^{\prime}$. $\lambda$ Draconis is evidently a slip of the pen for $\lambda$ Hydræ.-ED.]
The B.A. Unit

I WISH to call the attention of readers of NATURE who are interested in the experiments which have recently been made for the determination of the B.A. unit of resistance, to a paper by F. Koblrausch, read before the Academy of Sciences at Göttingen, September 6, I882, "On the Measurement by Llectrical means of the mean Area of the windings of a Coil." Prof, Kohlrausch has applied his method to redetermine the mean area of the coils of the earth inductor used by him in his experiments on the value of the B.A. unit in 1874 . He finds the area of this coil to be $387,200 \mathrm{sq} . \mathrm{cm}$. ; the value used in 1874 , calculater from the geometrical measurements of Weber in 1853 , was $392,800 \mathrm{sq} . \mathrm{cm}$. In consequence the value of the B.A. unit as determined from his experiments requires alteration, and, making the necessary corrections, Prof. Kohlrausch obtains I B.A. unit $=990 \times 10^{9} \frac{\mathrm{cm}}{\mathrm{sec}}$, agreeing much more nearly with the values found by Rowland, Rayleigh and Schuster, and myself.

Trinity College, Camkridge, October I3 R. T. Glazebrook

\section{The African Rivers and Meteorology}

THINkING that the following extract from a letter written from the Niger Delta may be of interest to your readers, I beg leave to offer it for insertion.

"As yet there has been little water in the Niger, the rise up to the present (August 29) has not been over 3 feet in the lower river, and they say no rise has taken place in the upper river as yet. The upper river commences at Locayo, or where the Benue or Chadda joins the Niger, and continues thence on to Timbuctoo. So far as I can foresee, there will be a famine in the Niger Valley this year, as there has been a complete failure of the first crop from drought, and there has been no chance of putting in the second crop for the same reason."

The regimen of the waters of such great rivers as the Nile, the Niger, and the Congo, both as to quantity and periods of rise and fall, mutst be closely related to the meteorological condition of the highlands of Africa, so little known to us, so extensive, and as yet so inaccessible for observation. May it not, therefore, be assumed that the comparative and continuous study and observation of those rivers as regards their volumes and pericd of rise and fall, would be likely to furnish most valuable da'a for the prediction or forecast of weather in Europe. Thinking so, I have suggested to my correspondent the advisability of keeping a systematic record of the rise of the river Niger, and, if possible, of the temperature and other conditions of the water, with a view to their utilisation for meteorological purposes, and from this point of view I have thcught that the above communi cation may present some interest. J. P. O'REIILY

Royal College of Science for Ireland, Dublin, October I 3

\section{A "Natura1" Experiment in Complementary Colours}

YESTERDAY evening I was reading Goethe's account of his visit to the falls of Schaffhausen (" Journey to Switzerland in 1797 "). After mentioning that the morning was a misty one, and describing the general effect of the cataract, he adds: "Wenn die strömenden Stellen grün aussehen, so erscheint der näcbste Gischt lei-e purpur gefärbt." I had certainly never heard of this phenomenon before, but it naturally occurred to me that it was probably an effect of complementary colours. Less than two hours afterwards I opened NATURE for the week, and found precicely the same phenomenon, with the same explanation as given by Mr. C. T. Whitmell. The point is interesting, as giving testimony to Goethe's close and accurate observation of colour phenomena; while the coincidence involved seems also to be worth recording. WALTER R. BROWNE

October I3

\section{Ventilation of Small Houses}

I HAVE been much interested in the reports of the Sanitary Institute. May I call attention to the fact that the majority of the smaller houses in our large towns have no means of ventilation except through the rooms. There are no ventilators or staircase windows, and the back bouse door opens into the kitchen. In a three-storied house the staircase is lit by the fanlight over the front door and a skylight in the roof, neither of 